\title{
Talpa fossilis or Talpa europaea? Using geometric morphometrics and allometric trajectories of humeral moles remains from Hungary to answer a taxonomic debate
}

\author{
Gabriele Sansalone, Tassos Kotsakis, and Paolo Piras
}

\begin{abstract}
The taxonomic validity of Talpa fossilis has been subject to a longstanding debate. Talpa fossilis has been considered as a chronospecies, stratigraphic species, and finally as junior synonym of Talpa europaea. In this study, the large humeral sample of $T$. fossilis and T. europaea from the Plio-Pleistocene of Hungary is re-investigated using a geometric morphometrics analysis. Furthermore, the differences in the static allometric slopes under the allometric constraint hypothesis were tested. The results indicate that $T$. fossilis and $T$. europaea have significant differences in both size and shape. The allometric slopes of $T$. fossilis and $T$. europaea were found to be different, revealing that the two taxa follow different patterns of shape modification according to size. In light of this evidence, $T$. fossilis and T. europaea are supported as two distinct species.
\end{abstract}

Gabriele Sansalone. Università di Roma Tre, Dipartimento di Scienze, L.S. Murialdo, 1 - 00146 Roma, Italy and Center of evolutionary ecology, Pesche, Italy. gsansalone@uniroma3.it

Tassos Kotsakis. Università di Roma Tre, Dipartimento di Scienze, L.S. Murialdo, 1 - 00146 Roma, Italy and Center of evolutionary ecology, Pesche, Italy. kotsakis@uniroma3.it

Paolo Piras. Università di Roma Tre, Dipartimento di Scienze, L.S. Murialdo, 1 - 00146 Roma, Italy and Center of evolutionary ecology, Pesche, Italy and Dipartimento di Scienze Cardiovascolari, Respiratorie, Nefrologiche, Anestesiologiche e Geriatriche, Sapienza-Universita` di Roma, Roma, Italy and Dipartimento di Ingegneria Strutturale e Geotecnica Sapienza, Università di Roma. paolo.piras@uniroma3.it

Keywords: Talpidae, geometric morphometrics, humerus, allometry, systematics, Plio-Pleistocene

Submission: 21 April, 2015 Acceptance: 22 July 2015

\section{INTRODUCTION}

Ontogenetic, static, and evolutionary allometries are recognized depending on whether the relationship between shape and size is taken over the development of an individual, across individu- als at a similar developmental stage within a population, or across separate evolutionary lineages (Cock, 1966; Gould, 1966; Cheverud, 1982). The allometric-constraint hypothesis states that the allometric slope remains stable at the above-spe-

Sansalone, Gabriele, Kotsakis, Tassos, and Piras, Paolo. 2015. Talpa fossilis or Talpa europaea? Using geometric morphometrics and allometric trajectories of humeral moles remains from Hungary to answer a taxonomic debate. Palaeontologia Electronica 18.2.42A: 117 
cies level and is able to constrain the evolutionary divergence in the morphospace along its specific trajectories (Firmat et al., 2014; Pélabon et al., 2014; Voje et al., 2014). Many recent comparative studies have provided evidence of the constraining role of static allometry, revealing that intraspecific static allometric trajectories remain constant through time (Voje and Hansen, 2013; Firmat et al., 2014; Voje et al., 2014). On the basis of the allometric-constraint hypothesis, statistically significant differences in static allometric slopes are not expected within the same species. Firmat et al. (2014), analysing a time-ordered sample of Mimomys savini, showed how the static allometric slopes remained constant through time. With the allometric-constraint as a background hypothesis, divergence in allometric slopes, in populations distributed across a time-ordered series, could indicate the presence of separate species. The humerus of highly fossorial moles is well suited for this kind of investigation, as this skeletal element is often abundant and well preserved in fossil assemblages.

Diverse lifestyles have evolved among Talpidae, which includes species that are ambulatory (the shrew-like moles), semi-aquatic (desmans), semi-fossorial (shrew moles), and fully fossorial (Hutchison, 1976; Yates and Moore, 1990). The fully fossorial taxa evolved a unique humeral morphology (Gambaryan et al., 2003; Sánchez-Villagra et al., 2004; Piras et al., 2012). As a result of the adaptation to burrowing, the humerus is widened and flattened, and presents an elliptically shaped, ventrally directed head of humerus, a heavily expanded proximal end, an enlarged teres major tubercle, a deep brachialis fossa, a large, hemicylindrical clavicular facet, and an enlarged medial epicondyle bearing a deep fossa for the attachment of the Flexor digitorum profundus tendon-muscle (Edwards, 1937; Hutchinson, 1968). The complexity of the humerus makes this bone a potentially rich source of evolutionary characters (Sánchez-Villagra et al., 2004); this bone experienced transformations that are of taxonomic and systematic interest (van den Hoek Ostende, 1997; Ziegler, 2003; Klietmann et al., 2014; Sansalone et al., in press).

Systematics and taxonomy of fossil moles have often been based on humeri, in particular when teeth materials are morphologically indistinguishable or very scarce (Ziegler, 2003). Moreover, many fossil species have been described on humeral remains alone (Ziegler, 2006). In the present contribution the humeral fossil material of Talpa fossilis and T. europaea from several Hungarian localities and from the German locality of Petersbuch 1 were re-investigated (Figure 1; Table 1). Hungarian localities provided a large amount of fossil material belonging to the genus Talpa. Classification of this material was based not only upon humeral remains, but also upon other skeletal elements, such as mandibles, teeth, and skull rostra (Petényi, 1864; Kormos, 1930; Kretzoi, 1938; Sulimski, 1959; Jánossy, 1979). The Late Pliocene-Middle Pleistocene Talpa material has been attributed to $T$. fossilis, whereas the Late-Pleistocene specimens to T. europaea (Jánossy, 1979). A geometric morphometric (GM) analysis of the humerus was used to quantitatively evaluate the differences (if any) in their shape and size as well as in their relationship. The static allometric trajectories of the two taxa were also investigated.

Pomel (1848), describing Talpa fossilis, suggested that the new species was somewhat larger and more robust and differed from other species in the shape of the carpals. However, the description made by Pomel (1848) has gone unnoticed since T. fossilis is attributed to Petényi (1864), who described $T$. vulgaris fossilis from the Hungarian fossil bearing locality of Beremend. The original description translated by van Cleef-Roders and van den Hoek Ostende (2001) states: "Talpa vulgaris fossilis Petényi. The fossil bone material of this animal totally agrees with the corresponding bones of the recent common mole, both in morphology and size; thus this fossil mole does not differ from the recent mole on the specific level, if one does not take into account the only difference noted by me, viz. that in the modern mole the labial side of the mandible has only two foramina mentale, one under the second premolar, the other under the first molar, whereas in the fossil mole three of such foramina are found, one under the first premolar, but two-be it one of them very shallow- under the first molar."

Following the original description of Petényi (1864), Talpa fossilis could not be distinguished from T. europaea Linnaeus, 1758, and justified a distinction only at subspecific level. Despite this, the middle-sized Talpa specimens from Late Pliocene to Middle Pleistocene deposits are often attributed to $T$. fossilis, whereas in more recent deposits they are often classified as $T$. europaea (Jánossy, 1979). Kormos (1930) described T. praeglacialis from the Early Pleistocene locality Püspokfürdo (Betfia 2), accounting for a higher number of foramina mentale than in $T$. europaea. Kretzoi (1938) then placed T. praeglacialis in syn- 


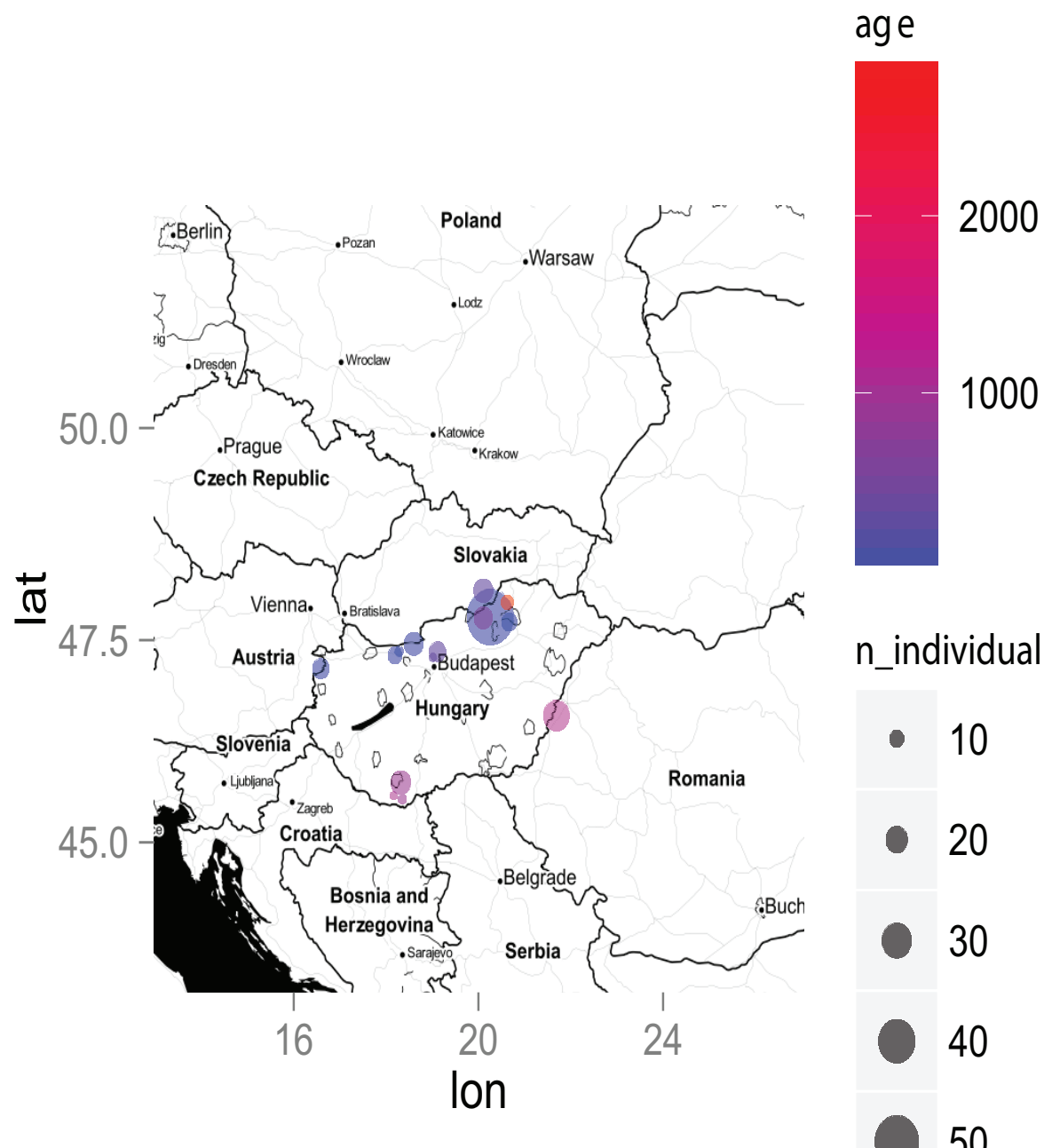

FIGURE 1. Geographical map showing the fossil bearing localities. Circles size is proportional to the number of individuals. Colour scale is proportional to relative age $(\mathrm{ka})$.

onymy with T. fossilis. Von Koenigswald (1970), in his discussion about the Talpa specimens from the German locality Petersbuch 1, suggested that there were no differences in size and morphology between $T$. fossilis and $T$. europaea. Rabeder (1972), in his discussion about the Talpa material from Hundsheim, suggested the presence of some slight morphological differences between $T$. fossilis and $T$. europaea such as the width of the M3 talonid and the number of the mental foramina. However, such differences were thought to be distinctive at the subspecific level only. Robert (1983), investigating the moles remains from the Middle Pleistocene of Saint Saveur, France, proposed to retain the name $T$. fossilis as a chronospecies since she observed a gradual size increase during the Pleistocene. Niethammer
(1990), following von Koenigswald (1970), considered $T$. fossilis as a stratigraphic species. However, van Cleef-Roders and van den Hoek Ostende (2001) pointed out that the material from Saint Saveur could be referred to $T$. caeca sensu latu because of the division of the mesostyle and the lack of humeri in the sample in addition to questioning the evolutionary trend proposed by Robert (1983). Van Cleef-Roders and van den Hoek Ostende (2001), reviewing the literature concerning $T$. fossilis, suggested considering $T$. fossilis as a junior synonym of $T$. europaea. They pointed out, however, that including all the material belonging to $T$. fossilis into $T$. europaea would probably be misleading. Thus, they noted the need for a more thorough review of the fossil assemblages bearing both taxa. 
TABLE 1. List of the fossil site localities, corresponding ages, and sample size of Talpa fossilis and T. europaea used in the analyses.

\begin{tabular}{|c|c|c|c|}
\hline Locality & Age & T. fossilis & T. europaea \\
\hline Osztramos 7 & MN16 (2.8 ma) & 1 & l \\
\hline Villany 3 & MN17 (2.3 ma) & 2 & l \\
\hline Betfia & Early Pleistocene & 5 & l \\
\hline Puspokfurdo & Early Pleistocene & 4 & l \\
\hline Beremend 15-16 & Early Pleistocene & 3 & I \\
\hline Somssich Hegy 2 & Middle Pleistocene & 3 & l \\
\hline Villany 8 & Middle Pleistocene & 11 & l \\
\hline Koversvarad & Middle Pleistocene & 9 & l \\
\hline Tarkò & Middle Pleistocene & 3 & l \\
\hline Brassò & Middle Pleistocene & 4 & l \\
\hline 25-Fortuna Utca, Budapest & Middle Pleistocene & 3 & l \\
\hline Petersbuch 1 & Middle Pleistocene & 3 & l \\
\hline Istalloskò & Late Pleistocene & I & 50 \\
\hline Bivak Barlang & Late Pleistocene & l & 6 \\
\hline Kofulke & Late Pleistocene & I & 4 \\
\hline Szelim Barlang & Late Pleistocene & l & 4 \\
\hline Koszeg-Puskaporos & Late Pleistocene & I & 3 \\
\hline
\end{tabular}

From this brief summary of the major contributions to the debate, it is evident that most researchers tend to consider Talpa fossilis as a subspecies or as a synonym of $T$. europaea. By contrast, many authors (Martín-Suárez and Mein, 2004; SánchezVillagra et al., 2004; Crochet et al., 2009; Colangelo et al., 2010; Rzebik-Kowalska, 2014) still consider the specific distinction as valid. Moreover, many of the measurements and morphological differences reported in the literature remain statistically untested. This study contributes to the debate by introducing the study of static allometric trajectories via geometric morphometrics (GM) analysis in order to reveal (if any) the potential different shape-size relationship between $T$. fossilis and $T$. europaea. Statistically significant differences in static allometric trajectories could suggest, on the basis of the allometric-constraint hypothesis (Firmat et al., 2014; Voje et al., 2014), that a specific distinction could be justified upon an inherent underlying biological process.

\section{MATERIAL AND METHODS}

\section{Material}

A total of 113 left humeri belonging to Talpa europaea Linnaeus, $1758(n=67)$ and Talpa fossilis Petényi, $1864(n=46)$ were analyzed. See
Table 1 and Figure 1 for specimen localities and corresponding ages. See Appendix 1 for specimen accession numbers and housing institutions.

\section{Geometric Morphometrics}

The humeri have been photographed in caudal view at a fixed distance of $50 \mathrm{~cm}$ with a Nikon D100 camera with a Micro-Nikkor $105 \mathrm{~mm}$ lens. We digitized 21 landmarks and 15 semi-landmarks (Figure 2.1) using the tpsDig2 software (Rohlf, 2006). Semi-landmarks are used to optimally translate, scale, and rotate landmarks, as well as to slide along the outline curve until they match as closely as possible the positions of the corresponding points along an outline in a reference configuration (Adams et al., 2004; Perez et al., 2006). Thus, semi-landmarks are useful to depict the shape of curved lines where landmarks cannot be detected. Successively a generalized procrustes analysis (GPA) (Bookstein, 1991; Goodall, 1991) implemented in the procSym() function from R-package "Morpho" (Schlager, 2014) was used to rotate, translate, and scale landmark configurations to the unit centroid size (CS = the square root of the sum of squared distances of a set of landmarks from their centroid) (Bookstein, 1986). Rotation of the scaled and translated landmark sets starts by comparison with a reference configuration, usually the 

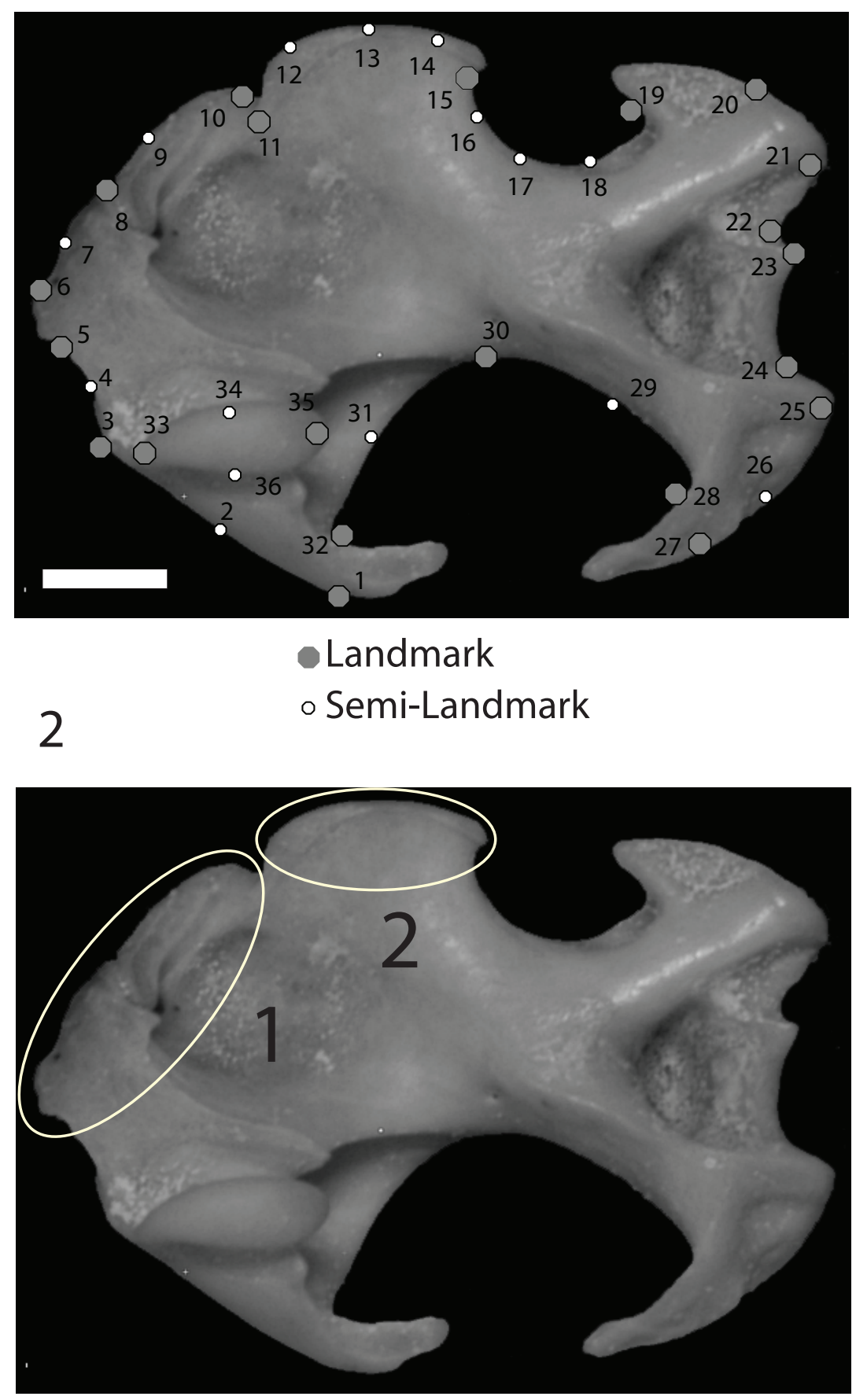

FIGURE 2. 1, Landmarks (large grey circles) and semilandmarks (small white circles) digitized on the humerus in caudal norm: 1) lateral end of greater tuberosity; 2) articular facet for clavicula; 3) proximal edge of the articular facet for clavicula; 4) bicipital notch; 5) proximal end of lesser tuberosity; 6) medial edge of the minor tuberosity; 7) lateral edge of the lesser tuberosity; 8) bicipital ridge; 9) middle point of the bicipital tunnel; 10) lateral end of the scalopine ridge; 11) proximal end of the teres tubercle; 12-14) surface of the teres tubercle; 15) distal end of the teres tubercle; 16-18) minor sulcus; 19) posterior margin of the lateral epicondyle; 21-22) lateral epicondyle; 22-24) trochlear area; 25-27) medial epicondyle; 28) posterior margin of the medial epicondyle; 29-32) greater sulcus; 33-36) humeral head. Scalebar equals $1 \mathrm{~mm}$. 2, Insertion areas of the main muscles involved in the digging movement. 1. Pectoral ridge where muscle Pectoralis pars sternalis inserts. 2. Teres tubercle where muscles Teres major and Latissimus dorsi inserts. 
first specimen in the dataset. Once the first rotation is completed, a mean shape is calculated and the rotation process is repeated using the mean shape as the reference configuration for the sample (including the reference-specimen configuration). The mean shape/rotation procedure is iterated to minimize rotation differences between subsequent iterations through a least-square procedure (Rohlf and Slice, 1990). The residual differences correspond to real shape differences plus measurement error. A principal components analysis (PCA) was used to visualize the ordination of the aligned specimens. The significance of the observed shape differences among species was evaluated by performing a permutational multivariate analysis of variance (perMANOVA) on procrustes coordinates using the adonis() function included in the "vegan" $R$ package (Oksanen et al., 2013). Deformations associated to the extreme of PC axes have been visualized through deformation grids. The grids have been built using the thin-plate spline methodology (Bookstein, 1989).

The significance of size differences has been evaluated by performing a permutational univariate analysis of variance (perANOVA) on CS using the function adonis(). Size variation was visualized using a boxplot.

\section{Measurement Error}

Measurement error associated with landmarks digitization was determined by first calculating the mean Procrustes distances between all combinations of two specimens in the dataset using TPSsmall software. The same values were then calculated for each cluster of replicas (three replicas were generated). The mean Procrustes distances were calculated for each set of replica's per specimen, including the same values for the total dataset. As an overall measure for digitisation error, the minimum and maximum values observed in all separate specimens were extracted, and the average of all mean values for those specimens was calculated. The amount of digitisation error with respect to the total variation in shape can be expressed as a percentage. Finally, the ratio of the mean value for total digitisation and the mean of the total dataset was calculated.

\section{Static Allometry}

The relationship between size (independent variable) and shape (dependent variable) was tested performing a multivariate regression of shape on size values averaged by species. All individuals analyzed are adult or subadult based on the ossification status of humeral epiphysis and diaphysis. Thus the allometric trajectories belong to the category of static allometry. A permutational multivariate analysis of covariance (perMANCOVA), using species as groups and size as covariate, was used to test for differences in slopes among species (Zelditch et al., 2004, 2012). This analysis was performed using the function adonis(). If slopes do not differ significantly (in this case the species and size interaction of the MANCOVA is not statistically significant), it is possible to control for the allometric effect and compute sizecorrected shape variables (Viscosi and Cardini, 2011; Viscosi et al., 2012; Zelditch et al., 2012). For the sake of visualization a canonical correlation analysis (CCA) was performed, which determines a $Y$ axis that represents the amount of $Y$ (shape variables) that is best explained by the independent variable $X(C S)$. In order to study interspecific shape differences, the intraspecific variation was removed by performing separate per-species multivariate regressions between shape and size. Then, for each species, the residuals were added to species specific shapes predicted at maximum and minimum, species-specific size values. This procedure ensures elimination of intraspecific allometry while maintaining the interspecific size-shape differences due to evolutionary allometry (Piras et al., $2011,2014)$. The differences between the predicted shape variables have been evaluated performing a perMANOVA using the function adonis(). This strategy, common in GM studies, allows the standardization of shape variables at determined size values (Zelditch et al., 2004, 2012). Finally, the Euclidean distances between shapes predicted at 10 equal CS values for Talpa fossilis and T. europaea were plotted in order to visualize the course of interspecific morphological distances along the static allometry.

\section{Variation Partitioning Analysis}

A variation partitioning analysis (VARPART) (Legendre and Legendre, 2012; Legendre et al., 2012) was performed to take into account the influence of space and climate on shape variables. The technique of variation partitioning is used when two or more complementary sets of hypotheses can be invoked to explain the variation of a response variable (Legendre, 2008). For this purpose, the latitude and longitude coordinates of each locality were transformed using the principal coordinates of neighbour matrices method (PCNM; Borcard and Legendre, 2002; Borcard et al., 2004). PCNM produces orthogonal (linearly independent) spatial 
TABLE 2. Results of the VARPART analysis.

\begin{tabular}{lcccc}
\hline Humeral shape/entire sample & $\mathbf{d f}$ & $\mathbf{R}^{\mathbf{2}}$ & Adjusted $\mathbf{R}^{\mathbf{2}}$ & $\mathbf{p}$ \\
\hline Full model & 7 & 0.17 & 0.12 & 0.001 \\
individual fractions & 1 & & & \\
pure time & 3 & 0.048 & 0.041 & 0.001 \\
$\begin{array}{l}\text { pure geography } \\
\text { pure climate }\end{array}$ & 1 & 0.05 & 0.026 & 0.001 \\
Humeral shape/Talpa europaea & & 0.009 & -0.005 & 0.858 \\
Full model & 5 & 0.11 & 0.04 & 0.002 \\
individual fractions & & & & \\
pure time & 1 & 0.01 & -0.002 & 0.678 \\
pure geography & 3 & 0.07 & 0.02 & 0.005 \\
pure climate & 1 & 0.009 & -0.005 & 0.879 \\
Humeral shape/Talpa fossilis & & & & \\
Full model & 5 & 0.13 & 0.032 & 0.056 \\
individual fractions & & & & \\
pure time & 1 & 0.04 & 0.029 & 0.128 \\
pure geography & 3 & 0.08 & 0.02 & 0.087 \\
pure climate & 1 & 0.035 & 0.014 & 0.059 \\
\hline
\end{tabular}

variables over a much wider range of spatial scales (Borcard and Legendre, 2002). The residuals of multivariate regression of the shape variables on the transformed geographical coordinates were calculated in order to remove the effect (if any) of spatial influence. Then, the residual scores to the mean shape value were summed. Once the spatial effect has been removed it is possible to run a perMANOVA test to ascertain if significant shape differences still occur among populations. It was hypothesized that a spatial influence would only occur for $T$. euroapea specimens.

The VARPART analysis was performed using the varpart() function in "vegan" $R$ package (Oksanen et al., 2013). The significance of the model was tested with a redundancy analysis (RDA). Climatic data were taken from Zachos et al. (2001). The oxygen isotopic data have been already used as a proxy for climatic changes in several previous works (Raia et al., 2005; Meloro et al., 2008; Sansalone et al., 2015) and was included as the climatic data in the VARPART model. The VARPART analysis was performed on the whole sample as well as on the separate samples of $T$. europaea and $T$. fossilis.

\section{RESULTS}

\section{Measurement Error}

The measurement error analysis revealed that $2.9 \%$ of the total variation was due to digitisation error. Since the measurement error was smaller than $5 \%$, it was judged as not significantly influencing further analysis.

\section{Variation Partitioning Analysis}

The results of the VARPART analysis are summarized in Table 2. A significant geographic and temporal interaction in the whole sample was found, whereas there was no correlation with climate. However, temporal and climate interactions were found to be negligible in both the separate species. A significant geographic influence was found only for Talpa europaea.

\section{Shape and Size Analyses}

The PCA performed on the aligned procrustes coordinates (Figure 3.1-2) show a good degree of separation between Talpa fossilis and T. europaea in particular along the PC1 $(17.18 \%$ of the total variance). At positive values of the PC1 the humeral morphology shows an enlargement of the pectoral ridge and of the teres tubercle, an enlargement of the greater tuberosity and a medial shift of the humeral head. At negative values of the PC1 it 

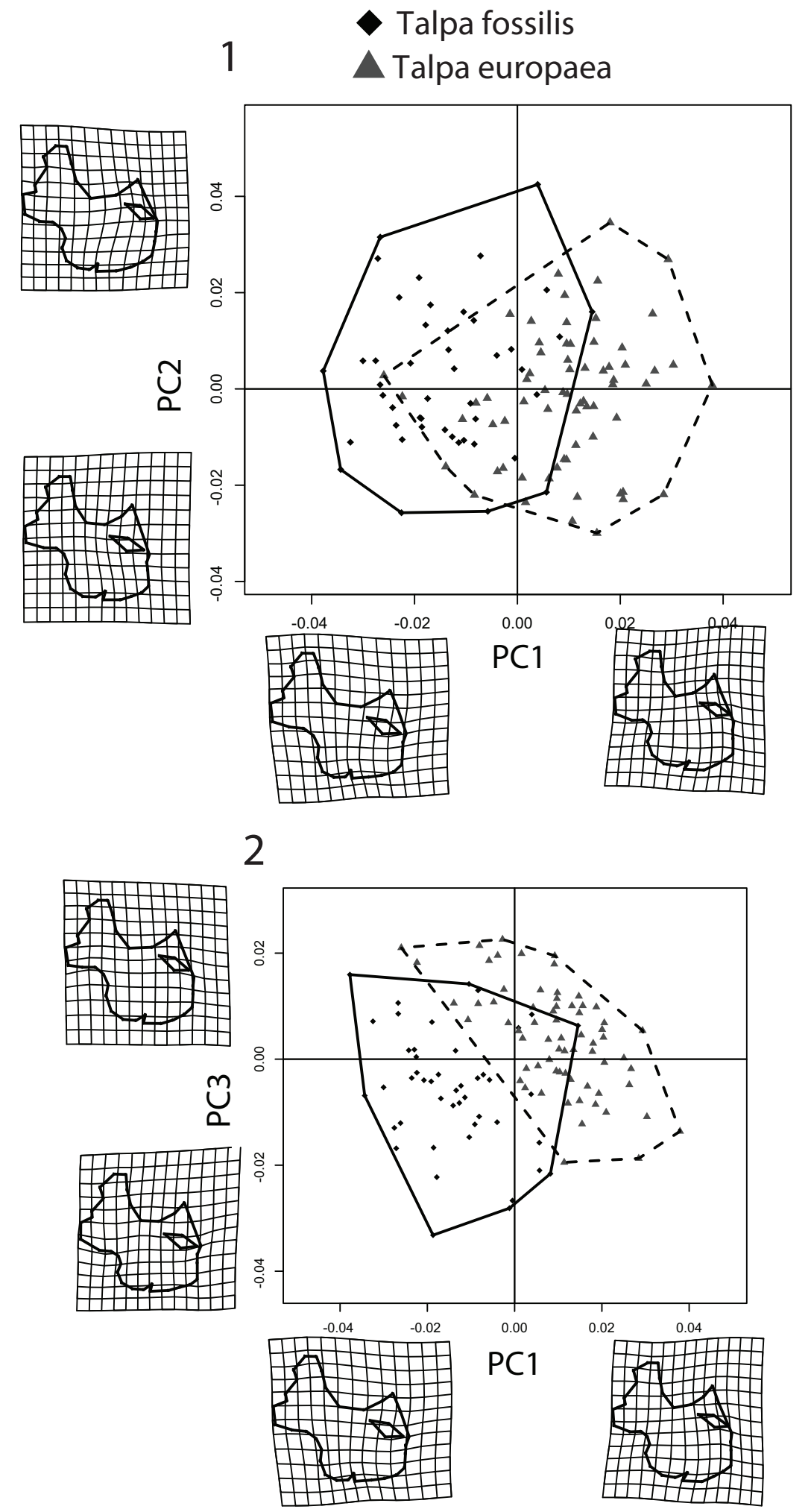

FIGURE 3. 1, Scatterplot of the first two axes of the PCA. Deformation grids refer to axes extremes (positive and negative values). 2, Scatterplot of the first and third axes of PCA. Deformation grids refer to axes extremes (positive and negative values). 
presents a contraction of the pectoral ridge and a reduction of the teres tubercle, a reduction of the greater tuberosity and a lateral shift of the humeral head. At positive values of the PC2 $(13.6 \%$ of the total variance) the humeral morphology shows an elongation of the teres tubercle and a shortening of the pectoral ridge. At negative values of the PC2 it shows a shortening of the teres tubercle and an elongation of the pectoral ridge. At positive values of the PC3 $(8.17 \%$ of the total variance) the humeral shape shows a contraction of the lateral epicondyle and an enlargement of the minor sulcus. At negative values of the PC3 it shows an enlargement of the lateral epicondyle and a contraction of the minor sulcus.

The perMANOVA test returned a statistically significant difference $\left(p<0.001 ; F_{1,111}=12.98\right)$ between the two species. Even when using the space corrected values for Talpa europaea the perMANOVA test returned a statistically significant result $\left(p<0.001 ; F_{1,111}=13.48\right)$. The boxplot computed for the CS (Figure 4) showed a statistically significant size variation (perANOVA, $p<0.001$; $F_{1,111}=46.041$ ) between $T$. europaea and $T$. fossilis, with the former being larger than the latter.

\section{Static Allometry}

According to the significant interaction ( $p=$ 0.0199; $F_{1}=1.92$ ) between species and size effects in the perMANCOVA, specific allometric trajectories were proved to be non-parallel between the two species. Multivariate regression of shape data on size returned a statistically significant result $\left(p<0.001 ; F_{1,109}=7.86 ; \mathrm{R}^{2}=0.061\right)$, with size accounting for $6 \%$ of the total shape variance (Figure 5.1). Separate multivariate regressions on Talpa fossilis and $T$. europaea returned statistically significant results $\left(p=0.003, \mathrm{R}^{2}=0.048 ; p<\right.$ $0.001, \mathrm{R} 2=0.034$; respectively). PerMANOVA returned statistically significant values for the shape variables standardized at maximum and minimum CS values $\left(p<0.001, F_{1,111}=26.51\right.$ and $p<0.001, F_{1,111}=12.09$; respectively). Euclidean distances show a decrement toward the CS value of 3.3 (though not becoming zero) from that value they tend to augment (Figure 5.2).

\section{DISCUSSION AND CONCLUDING REMARKS}

The separation between Talpa fossilis and $T$. europaea, observed along the PC1 (Figure 3.1-2), is due to changes in the teres tubercle and pectoral ridge. In particular, T. europaea has a larger teres tubercle and pectoral ridge than T. fossilis. In these humeral regions two of the main muscles associated with the burrowing motion are inserted (Figure 2.2) (Gambaryan et al., 2003; Piras et al., 2012, 2015). On the teres tubercle the Teres major and Latissimus dorsi muscles are inserted, while on the pectoral ridge the Pectoralis Pars Sternalis muscle inserts (Dobson, 1882; Freeman, 1886; Gambaryan et al., 2003). These muscles account for the $42.5 \%$ of the total digging muscle weight (Gambaryan et al., 2003). Piras et al. (2012) showed that the enlargement of the teres tubercle and of the pectoral ridge was a key factor in the evolution of fossoriality, and that the development of these anatomical regions significantly reduced the mechanic stress on the humerus across Talpidae phylogeny. Sansalone et al. (in press) re-assessed the taxonomy of the Plio-Pleistocene Neurotrichine moles and applied GM techniques on humeral remains. Their analysis showed the primitive morphology of the teres tubercle, pectoral ridge, and bicipital tunnel in the extinct Polish Rzebikia polonica and $R$. skoczeni, whereas the extant North American $\mathrm{Neu}$ rotrichus gibbsii was in a more derived state (Sansalone et al., in press). Within this framework, we suggest that $T$. europaea was better adapted to burrowing, as this taxon had a larger area of insertion for the main digging muscles and is more specialized than $T$. fossilis.

This study showed that the allometric trajectories of Talpa europaea and T. fossilis were significantly different (they cross each other) by having different starting and ending points. This evidence excludes the possibility that $T$. fossilis should be considered as a stratigraphic species (Rabeder, 1972). In this case we would expect to find very similar static allometric trajectories, as predicted by the allometric-constraint theory (Voje and Hansen, 2013; Firmat et al., 2014; Voje et al., 2014). The humerus of highly fossorial moles experienced a strong phenotypical channeling in order to adapt to the underground environment (Nevo, 1979; Sánchez-Villagra et al., 2006; Piras et al., 2012, 2015). The absence of a climatic influence on humeral shape, related to the climatic stability of the subterranean ecotope (Nevo, 1979), supports the evidence that the different allometric slopes likely indicate the presence of two separate species. Furthermore, the hypothesis that $T$. fossilis be considered a chronospecies of $T$. europaea (Robert, 1983) has been proven to be false. The significant shape differences found between $T$. europaea and $T$. fossilis, even when the shape variables are predicted at the same CS values, indicate that the two taxa have different allometric patterns and humeral 


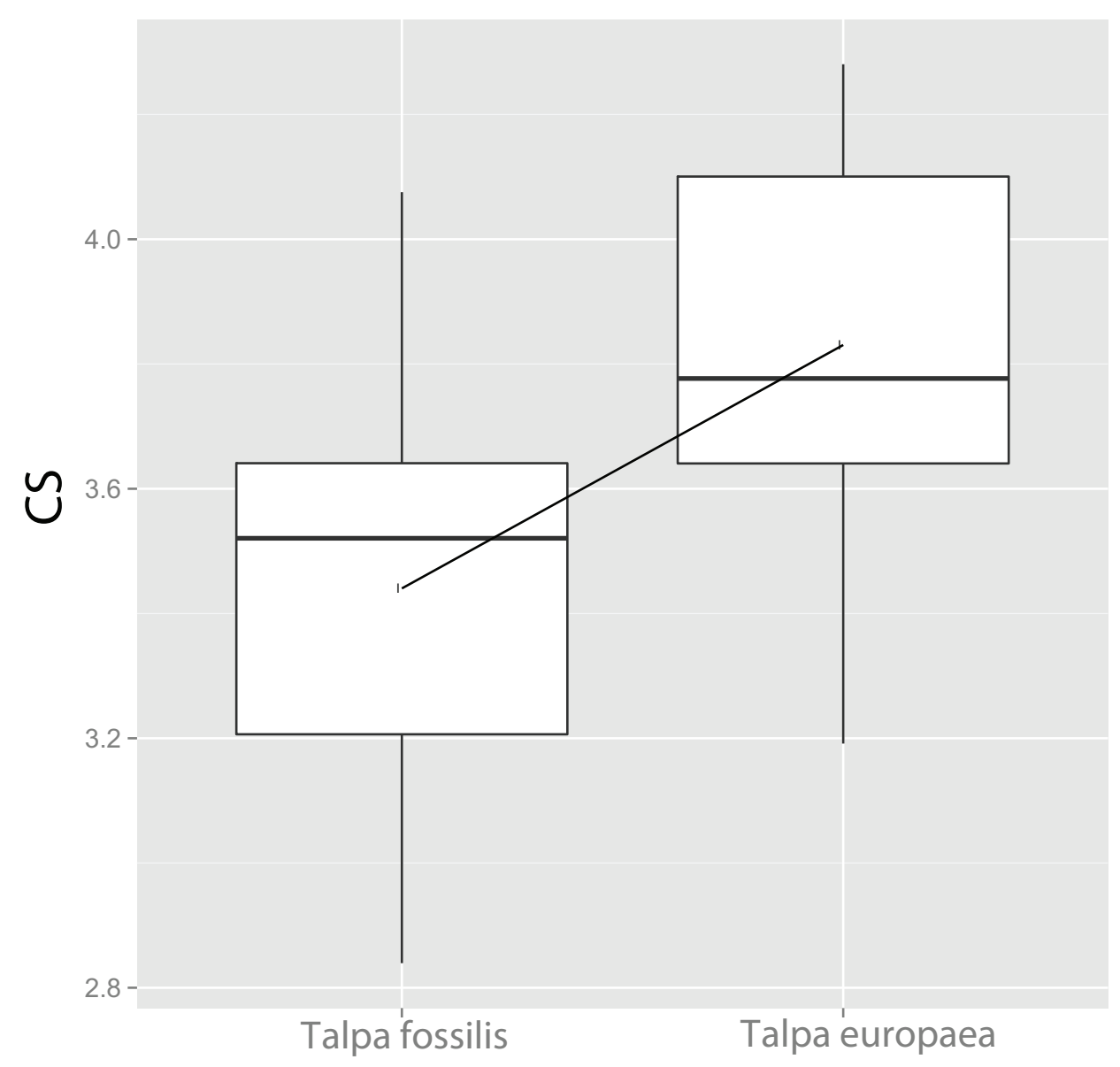

FIGURE 4. Boxplot of the centroid sizes. Bottom and top of the boxes are the first and third quartiles; horizontal solid black lines represent the median; whiskers represent the minimum and maximum values.

morphologies even under the same adaptive pressure.

Given these results Talpa fossilis is considered to be a distinct species from $T$. europaea. Separating these two taxa would also fit with molecular data. According to Colangelo et al. (2010) and Feuda et al. (2015) the T. europaea basal split has a mean divergence time estimate of 0.7 m.y. The time estimate would be in agreement with the fossil record and the species distinction usually presented in literature (Sulimski, 1959; Jánossy, 1979). From the results of this study, $T$. fossilis, which has a more primitive humeral morphology, is hypothesized to have originated from a different lineage than $T$. europaea. The fossil record (Ziegler, 1999; van den Hoek Ostende and Fejfar, 2006; Ziegler, 2006; Engesser, 2009) support the presence of four Talpa species since the early Miocene: T. tenuidentata Ziegler, 1990 (MN2-
3; 22-18 Ma), T. minuta de Blainville, 1840 (MN2-9; 22-10 Ma), T. vallesensis de Villalta Comella and Crusafont Pairó, 1944 (MN7-11; 12-8.5 Ma) and T. gilothi Storch, 1978 (MN9-11; 11.5-8.5 Ma). It is possible that the $T$. fossilis lineage originated from an offshoot of the Miocene mole lineages, which had a different allometric pattern and primitive humeral features, and spread across Europe during the Pliocene, surviving until the end of the Middle Pleistocene. In another possible scenario, $T$. fossilis could be derived from an eastern branch and may have colonized Europe during the Early Pliocene. According to Colangelo et al. (2010), T. europaea was derived from the eastern lineage of the genus Talpa. Therefore, it is hypothesized that $T$. europaea, during its colonization routes, could has come in contact with $T$. fossilis and out-competed it due to its larger size and superior digging capability. Competition in moles is a well-known 

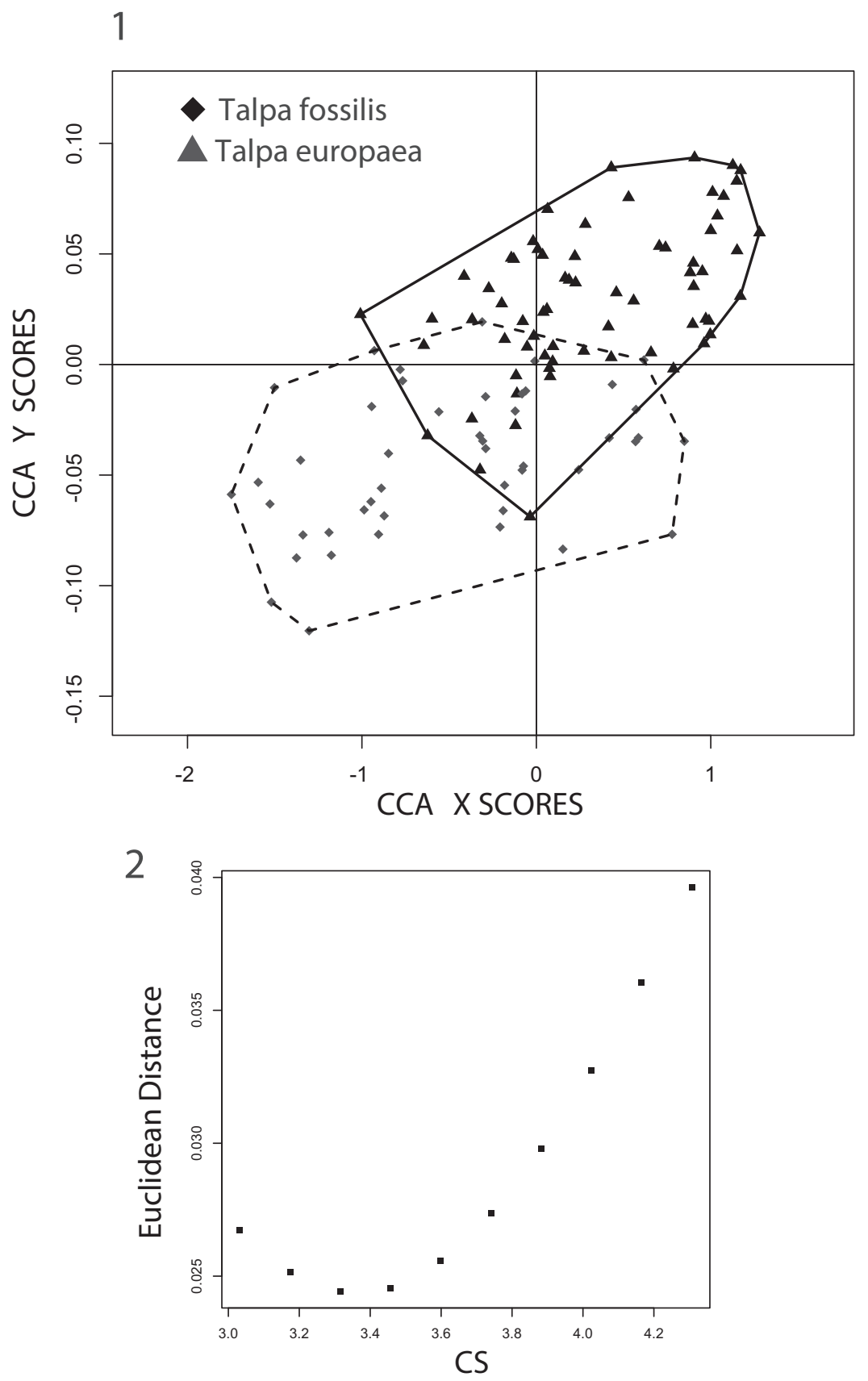

FIGURE 5. 1, CCA scatterplot of the shape and size variables. 2, Plot of the Euclidean distances between the predicted shape values of Talpa fossilis and T. europaea against 10 discrete CS intervals.

phenomenon and is described in detail for the genera Talpa and Mogera (Abe, 1996; Loy et al., 1996; Loy and Capanna, 1998; van Cleef-Roders and van den Hoek Ostende, 2001; Yokohata, 2005; Bego et al., 2008; Loy, 2008). Furthermore, highly fossorial moles have been extensively reported to be solitary, territorial, and actively patrolling their tunnels, which they defend against intruders (Gorman and Stone, 1990; Loy et al., 1994).
The results of this study suggest that the landmark-based shape analysis is useful in supporting systematics in palaeontological investigations, in particular when morphological differences are elusive. In order to extend these findings on humeral static allometric trajectories to larger portions of the occurrence areas of these two species, the systematics of every assemblage bearing Talpa fossilis and T. europaea should be reviewed, based not 
only on humeral morphologies, but also on other skeletal elements following the methodologies used in this study.

\section{ACKNOWLEDGEMENTS}

We are grateful to Dr. M. Gasparik from Natural History Museum, Budapest, Hungary and Prof. L. Kordos from Hungarian Geological Institute, Budapest, Hungary for allowing the visit of the Talpidae collection. We want to thank Dr. T. Matthews and an anonymous referee for their useful comments during the manuscript revision.

\section{REFERENCES}

Abe, H. 1996. Habitat factors affecting the geographic size variation of Japanese moles. Mammal Study, 21:71-87.

Adams, D.C., Rohlf, F.J., and Slice, D.E. 2004. Geometric morphometrics: Ten years of progress following the "revolution". Italian Journal of Zoology, 71:5 16.

Bego, F., Kryštufek, B., Paspali, G., and Rogozi, E. 2008. Small terrestrial mammals of Albania: annoted list and distribution. Hystrix, Italian Journal of Mammalogy, 19:83 101.

Bookstein, F.L. 1986. Size and shape spaces for landmark data in two dimensions. Statistical Science, 1:181 222.

Bookstein, F.L. 1989. Principal warps: thin-plate spline and the decomposition of deformations. Transactions on Pattern Analysis and Machine Intelligence, 6:567585.

Bookstein, F.L. 1991. Morphometric tools for landmark data. Cambridge University Press, Cambridge.

Borcard, D. and Legendre, P. 2002. All-scale spatial analysis of ecological data by means of principal coordinates of neighbour matrices. Ecological Model, 153:51-68.

Borcard, D., Legendre, P., Avois-Jacquet, C., and Tuomisto, H. 2004. Dissecting the spatial structure of ecological data at multiple scales. Ecology, 85:18261832.

Cheverud, J.M. 1982. Relationships among ontogenetic, static, and evolutionary allometry. American Journal of Physical Anthropology, 59:139-149.

Cock, A.G. 1966. Genetical aspects of metrical growth and form in animals. The Quarterly Review of Biology, 41:131-190.

Colangelo, P., Bannikova, A.A., Kryštufek, B., Lebedev, V.S., Annesi, F., Capanna, E., and Loy, A. 2010. Molecular systematics and evolutionary biogeography of the genus Talpa (Soricomorpha: Talpidae). Molecular Phylogenetic and Evolution, 35:372-380.

Crochet, J-Y., Welcomme, J-L., Ivorra, J., Ruffet, G., Boulbes, N., Capdevila, R., Claude, J., and Pickford, M. 2009. Une nouvelle faune de vertébrés continentaux, associée à des artefacts dans le Pléistocène inférieur de l'Hérault (Sud de la France), vers 1, 57 Ma. Comptes Rendus Palevol, 8:725-736.

de Blainville, H.M.D. 1838-1840. Ostéographie des mammifères insectivores. In de Blainville, H.M.D. (1864). Ostéographie ou description iconographique comparée du squelette et du système dentaire des mammifères récent et fossiles pour servir de base à la zoologie et à la géologie. $4^{\circ}$ livraison $6,115 \mathrm{pp}$. Paris.

de Villalta Comella, J.F. and Crusafont Pairó, M. 1944. Nuevos insectivoros del Mioceno Continental del Vallés-Panadés. Notas Commissiones Institutos de Geologia y Mineralogia de España, 12:41-65.

Dobson, G.E. 1882. A monograph of the Insectivora. Part II. John Van Voorst, London.

Edwards, L.F. 1937. Morphology of the fore-limb of the mole (Scalops aquaticus, L.) in relation to its fossorial habits. Ohio Journal of Science, 37:20-41.

Engesser, B. 2009. The insectivores (mammalia) from Sansan (middle miocene, south-western France). Schweizerischen Paläontologischen Abhandlungen, 128:1-91.

Feuda, R., Bannikova, A.A., Zemlemerova, E.D., Di Febbraro, M., Loy, A., Hutterer, R., Aloise, G., Zykov, A.E., Annesi, F., and Colangelo, P. 2015. Tracing the evolutionary history of the mole, Talpa europaea, through mitochondrial DNA phylogeography and species distribution modelling. Biological Journal of the Linnean Society 114:495-512.

Firmat, C., Lozano-Fernández, I., Agustí, J., Bolstad, G.H., Cuenca-Bescós, G., Hansen, T.F., and Pélabon, C. 2014. Walk the line: 600000 years of molar evolution constrained by allometry in the fossil rodent Mimomys savini. Philosophical Transactions of the Royal Society B: Biological Sciences, 369(1649), 20140057.

Freeman, R.A. 1886. The anatomy of the shoulder and upper arm of the mole (Talpa europaea). Journal of Anatomy and Physiology, 20:201-219.

Gambaryan, P., Gasc, J.P., and Renous, S. 2003. Cinefluorographical study of the burrowing movements in the common mole, Talpa europaea (Lipotyphla, Talpidae). Russian Journal of Theriology, 1:91-109.

Goodall, C. 1991. Procrustes methods in the statistical analysis of shape. Journal of the Royal Statistical Society, 53:285-339.

Gorman, M.L. and Stone, R.D. 1990. The natural history of the mole. Cristopher Helm, London.

Gould, S.J. 1966. Allometry and size in ontogeny and phylogeny. Biological Review of the Cambridge Philosophical Society, 41:587-640.

Hutchison, J.H. 1968. Fossil Talpidae (Insectivora, Mammalia) from the later Tertiary of Oregon. Bulletin of the Museum of Natural History University of Oregon, 11:1-117.

Hutchison, J.H. 1976. The Talpidae (Insectivora, Mammalia): Evolution, Phylogeny, and Classification. PhD Thesis, University of California, Berkeley. 
Jánossy, D. 1979. A magyarorszàgy pleisztocèn tagolasa gerinces faunàk alapjàn. Akademia Kiadò, Budapest. (English Translation: 1986 - Pleistocene vertebrate fauna of Hungary. 208 pp. Elsevier, Amsterdam).

Klietmann, J., Nagel, D., Rummel, M., and van den Hoek Ostende, L.W. 2014. A gap in digging: the Talpidae of Petersbuch 28 (Germany, Early Miocene). Paläontologische Zeitschrift 1-30. DOI 10.1007/s12542-0140228-2

Kormos, T. 1930. Diagnosen neuer Säugetiere aus des oberpliozänen Fauna des Somlyöberges, Püspokfürdo. Annales Historico-Naturales Musei Nationalis Hungarici, 27:237 246.

Kretzoi, M. 1938. Die Raubtiere von Gombaszög nebst einer Übersicht der Gesamtfauna. Annales HistoricoNaturales Musei Nationalis Hungarici, 31:88 157.

Legendre, P. 2008. Studying beta diversity: ecological variation partitioning by multiple regression and canonical analysis. Journal of Plant Ecology, 1:3-8.

Legendre, P. and Legendre, L., 2012. Numerical Ecology, Third English edition. Elsevier Science BV, Amsterdam, The Netherlands.

Legendre, P., Borcard, D., and Roberts, D.W. 2012. Variation partitioning involving orthogonal spatial eigenfunction submodels. Ecology, 93:1234-1240.

Linnaeus, C. 1758. Systema naturae per regna tria naturae, secundum classes, ordines, genera, species cum characteribus, differentiis, synonymis, locis. 10th edition, 1/1, Laurentii Salvii; Stockholm.

Loy, A. 2008. Famiglia Talpidae. In Amori G., Contoli L., Nappi, A. (eds.), Mammalia II. Erinaceomorpha, Soricomorpha, Lagomorpha, Rodentia. Fauna d'Italia, vol. XLIV, Calderini, Bologna: 91-130.

Loy, A., Beolchini, F., Martullo, S., and Capanna, E. 1994. Territorial behaviour of Talpa romana in an olivegrove habitat in central Italy. Italian Journal of Zoology, 61:207-211.

Loy, A. and Capanna, E. 1998. A parapatric contact area between two species of moles (genus Talpa): character displacement investigated through the geometric morphometric of skull. Acta Zoologica Academiae Scientiarum Hungaricae, 44:151-164.

Loy, A., Di Martino, S., and Capolongo, D. 1996. Patterns of geographic variation of Talpa romana Thomas: preliminary results derived from a geometric morphometric approach. Mammalia, 60:77-89.

Martìn-Suárez, E. and Mein, P. 2004. The Late Pliocene locality of Saint-Vallier (Drôme, France). Eleven micromammals. Geobios, 37:115-125.

Meloro, C., Raia, P., Carotenuto, F., and Barbera, C. 2008. Diversity and turnover of Plio-Pleistocene large mammal fauna from the Italian Peninsula. Palaeogeography, Palaeoclimatology, Palaeoecology, 268:5864.

Nevo, E. 1979. Adaptive convergence and divergence of subterranean mammals. Annual Review of Ecology and Systematics, 20:269-308.
Niethammer, J. 1990. Talpa, p. 93-161. In Niethammer, J. and Krapp F. (eds.), Handbuch der Säugetiere Europas. Bd. 3. Insektenfresser-Insectivora, Herrentiere-Primates. Wiesbaden.

Oksanen, J., Blanchet, F.G., Kindt, R., Legendre, P., Minchin, P.R., O'Hara, R.B., Simpson, G.L., Solymos, P., Henry, M., Stevens, H., and Wagner, H. 2013. Vegan: Community Ecology Package. R-package version 2.0-7. Available at CRAN.R-project.org/package=vegan .

Pélabon, C., Firmat, C., Bolstad, G.H., Voje, K.L., Houle, D., Cassara, J., Rouzic, A.L., and Hansen, T.F. 2014. Evolution of morphological allometry. Annals of the New York Academy of Sciences, 1320:58-75.

Perez, S.I., Bernal, V., and Gonzalez, P.N. 2006. Differences between sliding semi-landmark methods in geometric morphometrics, with an application to human cranio-facial and dental variation. Journal of Anatomy, 208:769-784.

Petényi, S.J. 1864. Hátrahagyott munkái. 130 pp. Pest. (In Hungarian: A beremendi mészköbánya természetrajz- és öslénytanilag leírva. 35-81; posthumous work).

Piras, P., Buscalioni, A.D., Teresi, L., Raia, P., SansaIone, G., Kotsakis, T., and Cubo, J. 2014. Morphological integration and functional modularity in crocodilian skull. Integrative Zoology, 9:498-516.

Piras, P., Sansalone, G., Colangelo, P., Teresi, L., Kotsakis, T., and Loy, A. 2012. Testing convergent and parallel adaptations in talpids humeral mechanical performance by means of Geometric Morphometrics and Finite Element Analysis. Journal of Morphology, 273:696 711.

Piras, P., Salvi, D., Ferrara, G., Maiorino, L., Delfino, M., Pedde, L., and Kotsakis, T. 2011. The role of postnatal ontogeny in the evolution of phenotypic diversity in Podarcis lizards. Journal of Evolutionary Biology, 24:2705-2720.

Piras, P., Sansalone, G., Teresi, L., Moscato, M., Profico, A., Eng, R., Cox, T.C., Loy, A., Colangelo, P., and Kotsakis, T. 2015. Digging adaptation in insectivorous subterranean eutherians. The enigma of Mesoscalops montanensis unveiled by geometric morphometrics and finite element analysis. Journal of Morphology, DOI: 10.1002/jmor.20405

Pomel, A. 1848. Étude sur les carnassiers insectivores. I Insectivores fossiles. II Classification des insectivores. Archives des Sciences Physiques et Naturelles, 9:159-165; 244-251.

Rabeder, G. 1972. Die Insectivoren und Chiropteren (Mammalia) aus dem Altpleistozän von Hundsheim (Niederösterreich). Annalen des Naturhistorischen Museums in Wien, 76:375-474.

Raia, P., Piras, P., and Kotsakis, T. 2005. Turnover pulse or Red Queen? Evidence from the large mammal communities during the Plio-Pleistocene of Italy. Palaeogeography, Palaeoclimatology, Palaeoecology, 221:293-312. 
Robert, C. 1983. Recherches sur les Taupes (Talpa, Insectivora) de quelques gisements quaternaires de France. Thesis Université de Bordeaux I, 170 pp.

Rohlf, F.J. 2006. TpsDig 2.05. Department of Ecology and Evolution, State University of NY, Stony Brook, NY. Available at life.bio.sunysb.edu/morph/

Rohlf, F.J. and Slice, D.E. 1990. Extensions of the Procrustes method for the optimal superimposition of landmarks. Systematic Zoology, 39:40 59.

Rzebik-Kowalska, B. 2014. Revision of the Pliocene and Pleistocene Talpidae (Soricomorpha, Mammalia) of Poland. Palaeontologia Electronica, 17:1-26.

Sánchez-Villagra, M.R., Horovitz, I., and Motokawa, M. 2006. A comprehensive morphological analysis of talpid moles (Mammalia) phylogenetic relationship. Cladistics, 22:59-88.

Sánchez-Villagra, M.R., Menke, P.R., and Geisler, J.H. 2004. Patterns of evolutionary transformation in the humerus of moles (Talpidae, Mammalia): a character analysis. Mammal Study, 29:163-170.

Sansalone, G., Bertè, D.F., Maiorino, L., and Pandolfi, L. 2015. Evolutionary trends and stasis in carnassial teeth of European Pleistocene wolf Canis lupus (Mammalia, Canidae). Quaternary Science Reviews, 110:36-48.

Sansalone, G., Kotsakis, T., and Piras, P. in press. New systematic insights about Plio-Pleistocene moles from Poland. Acta Palaeontologica Polonica, DOI: dx.doi.org/10.4202/app.00116.2014

Schlager, S. 2014. Morpho: Calculations and visualisations related to Geometric Morphometrics. R-package version 2.0.3-1. Available at http://cran.rproject.org/web/packages/Morpho/index.html.

Storch, G. 1978. Die turolische Wirbeltierfauna von DornDürkheim, Rheinhessen (SW Deutschland). 2. Mammalia: Insectivora. Senckenbergiana Lethaea, 58:421-449.

Sulimski, A. 1959. Pliocene insectivores from Weze. Acta Palaeontologica Polonica, 4:119-177.

van Cleef-Roder, J.T. and van den Hoek Ostende, L.W. 2001. Dental morphology of Talpa europaea and Talpa occidentalis (Mammalia: Insectivora) with a discussion of fossil Talpa in the Pleistocene of Europe. Zoologische Mededelingen, 75:51-68.

van den Hoek Ostende, L.W. 1997. Insectivore faunas from the Lower Miocene of Anatolia. Part 4: The genus Desmanodon (Talpidae) with the description of a new species from the Lower Miocene of Spain. Proceedings Koninklijke Akademie van Wetenschappen, 100:27-65.

van den Hoek Ostende, L.W. and Fejfar, O. 2006. Erinaceidae and Talpidae (Erinaceomorpha, Soricomorpha, Mammalia) from the Lower Miocene of MerkurNord (Czech Republic, MN 3). Beiträge zur Paläontologie 30:175-203.
Viscosi, V., Antonecchia, G., Lepais, O., Fortini, P., Gerber, S., and Loy, A. 2012. Leaf shape and size differentiation in white oaks: assessment of allometric relationships among three Sympatric species and their hybrids. International Journal of Plant Science, 173:875-884.

Viscosi, V. and Cardini, A. 2011. Leaf morphology, taxonomy and geometric morphometrics: a simplified protocol for beginners. PLoS One, 6(10), e25630.

Voje, K.L. and Hansen, T.F. 2013. Evolution of static allometries: adaptive change in allometric slopes of eye span in stalk-eyed flies. Evolution, 67:453-467.

Voje, K.L., Hansen, T.F., Egset, C.K., Bolstad, G.H., and Pèlabon, C. 2014. Allometric constraints and the evolution of allometry. Evolution, 68:866-885.

von Koenigswald, W. 1970. Mittelpleistozäne Kleinsäugerfauna aus der Spaltenfüllung Petersbuch bei Eichstätt. Mitteilungen der Bayerischen Staatssammlung für Paläontologie und Historische Geologie, 10:407 432 .

Yates, T.L. and Moore, D.W. 1990. Speciation and evolution in the family Talpidae (Mammalia: Insectivora), p. 1-22. In Nevo, E. and Reig, O.A. (eds.), Evolution of Subterranean Mammals at the Organismal and Molecular Levels. Wiley-Liss, New York.

Yokohata, Y. 2005. A brief review of the biology on moles in Japan. Mammal Study, 30:25-30.

Zachos, J., Pagani, M., Sloan, L., Thomas, E., and Billups, K. 2001. Trends, rhythms, and aberrations in global climate $65 \mathrm{Ma}$ to present. Science, 292:686693.

Zelditch, M.L., Swiderski, D.L., and Sheets, H.D. 2012. Geometric Morphometrics for Biologists: A Primer. 488 pp. 2nd ed. Elsevier - Academic Press. San Diego, CA.

Zelditch, M.L., Swiderski, D.L., Sheets, H.D., and Fink W.L. 2004. Geometric Morphometrics for Biologists: A Primer. 437 pp. Elsevier - Academic Press. San Diego, CA.

Ziegler, R. 1990. Talpidae (Insectivora, Mammalia) aus dem Oberoligozan und Untermiozan Süd-deutschlands. Stuttgarter Beiträge für Naturkunde B, 167:181.

Ziegler, R. 1999. Order Insectivora. In Rössner, G.E. and Heissig, K. (eds.), The Miocene Land Mammals of Europe, Verlag Dr. Friedrich Pfeil, München, p. 5374.

Ziegler, R. 2003. Moles (Talpidae) from the late Middle Miocene of South Germany. Acta Palaeontologica Polonica, 48:617-648.

Ziegler, R. 2006. Insectivores (Lipotyphla) and bats (Chiroptera) from the Late Miocene of Austria. Annalen des Naturhistorischen Museums in Wien A, 107:93196. 


\section{APPENDIX.}

Specimen accession numbers and housing institutions.

\begin{tabular}{|c|c|c|}
\hline Species & Accession number & Housing Institution \\
\hline Talpa fossilis & 3701_01 & Budapest Natural History Museum \\
\hline Talpa fossilis & 3701_02 & Budapest Natural History Museum \\
\hline Talpa fossilis & 3701_03 & Budapest Natural History Museum \\
\hline Talpa fossilis & 3701_04 & Budapest Natural History Museum \\
\hline Talpa fossilis & 4721 & Budapest Natural History Museum \\
\hline Talpa fossilis & 4741_01 & Budapest Natural History Museum \\
\hline Talpa fossilis & 4741_02 & Budapest Natural History Museum \\
\hline Talpa fossilis & 4741_03 & Budapest Natural History Museum \\
\hline Talpa fossilis & 4750_01 & Budapest Natural History Museum \\
\hline Talpa fossilis & 4750_02 & Budapest Natural History Museum \\
\hline Talpa fossilis & B_01 & Budapest Natural History Museum \\
\hline Talpa fossilis & B_02 & Budapest Natural History Museum \\
\hline Talpa fossilis & 3702 & Budapest Natural History Museum \\
\hline Talpa fossilis & Villany_08_10_01 & Budapest Natural History Museum \\
\hline Talpa fossilis & Villany_08_10_02 & Budapest Natural History Museum \\
\hline Talpa fossilis & Villany_08_10_03 & Budapest Natural History Museum \\
\hline Talpa fossilis & Villany_08_10_04 & Budapest Natural History Museum \\
\hline Talpa fossilis & Villany_08_10_05 & Budapest Natural History Museum \\
\hline Talpa fossilis & Villany_08_10_06 & Budapest Natural History Museum \\
\hline Talpa fossilis & Villany_08_10_07 & Budapest Natural History Museum \\
\hline Talpa fossilis & Villany_08_10_08 & Budapest Natural History Museum \\
\hline Talpa fossilis & Villany_08_10_09 & Budapest Natural History Museum \\
\hline Talpa fossilis & Villany_08_10_10 & Budapest Natural History Museum \\
\hline Talpa fossilis & Villany_08_10_11 & Budapest Natural History Museum \\
\hline Talpa fossilis & Villany_08_11_01 & Budapest Natural History Museum \\
\hline Talpa fossilis & Villany_08_11_02 & Budapest Natural History Museum \\
\hline Talpa fossilis & Villany_08_11_03 & Budapest Natural History Museum \\
\hline Talpa fossilis & Villany_08_11_04 & Budapest Natural History Museum \\
\hline Talpa fossilis & Villany_08_12a & Budapest Natural History Museum \\
\hline Talpa fossilis & V_65482 & Budapest Natural History Museum \\
\hline Talpa fossilis & Somssichhegy_4_1 & Budapest Natural History Museum \\
\hline Talpa fossilis & Somssichhegy_4_2 & Budapest Natural History Museum \\
\hline Talpa fossilis & Ostramos_7_01 & Budapest Natural History Museum \\
\hline Talpa fossilis & Ostramos_7_02 & Budapest Natural History Museum \\
\hline Talpa fossilis & 4743_01 & Budapest Natural History Museum \\
\hline Talpa fossilis & 4743_02 & Budapest Natural History Museum \\
\hline Talpa fossilis & 4743_03 & Budapest Natural History Museum \\
\hline Talpa fossilis & 4743_04 & Budapest Natural History Museum \\
\hline Talpa fossilis & 4743_05 & Budapest Natural History Museum \\
\hline Talpa fossilis & 4743_06 & Budapest Natural History Museum \\
\hline
\end{tabular}


Sansalone, Kotsakis, \& Piras: Plio-Pleistocene moles

\begin{tabular}{|c|c|c|}
\hline Species & Accession number & Housing Institution \\
\hline Talpa fossilis & 4743_07 & Budapest Natural History Museum \\
\hline Talpa fossilis & 4743_08 & Budapest Natural History Museum \\
\hline Talpa fossilis & 4743_09 & Budapest Natural History Museum \\
\hline Talpa fossilis & 4743_10 & Budapest Natural History Museum \\
\hline Talpa fossilis & HP18 & BSPG Munich Natural History Museum \\
\hline Talpa fossilis & 5.24 & BSPG Munich Natural History Museum \\
\hline Talpa fossilis & $5.24 a$ & BSPG Munich Natural History Museum \\
\hline Talpa europaea & V57760_01 & Budapest Natural History Museum \\
\hline Talpa europaea & V57760_02 & Budapest Natural History Museum \\
\hline Talpa europaea & V57760_03 & Budapest Natural History Museum \\
\hline Talpa europaea & V57760_04 & Budapest Natural History Museum \\
\hline Talpa europaea & V57760_05 & Budapest Natural History Museum \\
\hline Talpa europaea & V_59143 & Budapest Natural History Museum \\
\hline Talpa europaea & V_59145_01 & Budapest Natural History Museum \\
\hline Talpa europaea & V_59145_02 & Budapest Natural History Museum \\
\hline Talpa europaea & V_59145_03 & Budapest Natural History Museum \\
\hline Talpa europaea & V_59145_04 & Budapest Natural History Museum \\
\hline Talpa europaea & V_59145_05 & Budapest Natural History Museum \\
\hline Talpa europaea & V_59145_06 & Budapest Natural History Museum \\
\hline Talpa europaea & V_59145_07 & Budapest Natural History Museum \\
\hline Talpa europaea & V_59145_08 & Budapest Natural History Museum \\
\hline Talpa europaea & V_59145_09 & Budapest Natural History Museum \\
\hline Talpa europaea & V_5915_01 & Budapest Natural History Museum \\
\hline Talpa europaea & V_5915_02 & Budapest Natural History Museum \\
\hline Talpa europaea & V_5915_03 & Budapest Natural History Museum \\
\hline Talpa europaea & V_5915_04 & Budapest Natural History Museum \\
\hline Talpa europaea & V_5915_05 & Budapest Natural History Museum \\
\hline Talpa europaea & V_5915_06 & Budapest Natural History Museum \\
\hline Talpa europaea & V_5915_07 & Budapest Natural History Museum \\
\hline Talpa europaea & V_5915_08 & Budapest Natural History Museum \\
\hline Talpa europaea & V_5915_09 & Budapest Natural History Museum \\
\hline Talpa europaea & V_5915_10 & Budapest Natural History Museum \\
\hline Talpa europaea & V_5915_11 & Budapest Natural History Museum \\
\hline Talpa europaea & V_5917_01 & Budapest Natural History Museum \\
\hline Talpa europaea & V_5917_02 & Budapest Natural History Museum \\
\hline Talpa europaea & V_5917_03 & Budapest Natural History Museum \\
\hline Talpa europaea & V_5917_04 & Budapest Natural History Museum \\
\hline Talpa europaea & V_5917_05 & Budapest Natural History Museum \\
\hline Talpa europaea & V_5917_06 & Budapest Natural History Museum \\
\hline Talpa europaea & V_5917_07 & Budapest Natural History Museum \\
\hline Talpa europaea & V_5917_08 & Budapest Natural History Museum \\
\hline Talpa europaea & V_5917_09 & Budapest Natural History Museum \\
\hline
\end{tabular}




\begin{tabular}{|c|c|c|}
\hline Species & Accession number & Housing Institution \\
\hline Talpa europaea & V_5917_10 & Budapest Natural History Museum \\
\hline Talpa europaea & V_5917_11 & Budapest Natural History Museum \\
\hline Talpa europaea & V_5917_12 & Budapest Natural History Museum \\
\hline Talpa europaea & V_5917_13 & Budapest Natural History Museum \\
\hline Talpa europaea & V_5917_14 & Budapest Natural History Museum \\
\hline Talpa europaea & V_5917_15 & Budapest Natural History Museum \\
\hline Talpa europaea & V_5917_16 & Budapest Natural History Museum \\
\hline Talpa europaea & V_5917_17 & Budapest Natural History Museum \\
\hline Talpa europaea & V_5917_18 & Budapest Natural History Museum \\
\hline Talpa europaea & V_5917_19 & Budapest Natural History Museum \\
\hline Talpa europaea & V_5917_20 & Budapest Natural History Museum \\
\hline Talpa europaea & V_5917_21 & Budapest Natural History Museum \\
\hline Talpa europaea & V_5917_22 & Budapest Natural History Museum \\
\hline Talpa europaea & V_5917_23 & Budapest Natural History Museum \\
\hline Talpa europaea & V_5917_24 & Budapest Natural History Museum \\
\hline Talpa europaea & V_5917_25 & Budapest Natural History Museum \\
\hline Talpa europaea & V_5917_26 & Budapest Natural History Museum \\
\hline Talpa europaea & V_5917_27 & Budapest Natural History Museum \\
\hline Talpa europaea & V_5917_28 & Budapest Natural History Museum \\
\hline Talpa europaea & V_5917_29 & Budapest Natural History Museum \\
\hline Talpa europaea & V_5917_30 & Budapest Natural History Museum \\
\hline Talpa europaea & V_5917_31 & Budapest Natural History Museum \\
\hline Talpa europaea & V_5917_32 & Budapest Natural History Museum \\
\hline Talpa europaea & V_5917_33 & Budapest Natural History Museum \\
\hline Talpa europaea & V_621116 & Budapest Natural History Museum \\
\hline Talpa europaea & V_621172_01 & Budapest Natural History Museum \\
\hline Talpa europaea & V_621172_02 & Budapest Natural History Museum \\
\hline Talpa europaea & V_621172_03 & Budapest Natural History Museum \\
\hline Talpa europaea & V_621172_04 & Budapest Natural History Museum \\
\hline Talpa europaea & V_621172_05 & Budapest Natural History Museum \\
\hline Talpa europaea & V_631274 & Budapest Natural History Museum \\
\hline
\end{tabular}

